\title{
Editorial
}

Editorial titles in REFUGE, Volume 6, during the past year chronicled a saga from celebration to crisis. Thus we moved from A Time to Rejoice [Nansen Medal]...Hope for Refugees in 1987? [policy delays]...The Trust of the People of Canada [effects of border closing on Salvadoran and Guatemalan refugees] to Asylum in North America: Crisis. During the past year we have witnessed a distinct resurgence of discriminatory governmental practices in processing inland refugee claimants. All persons fleeing persecution have been assured of their right to asylum by enshrined Conventions of the United Nations High Commission for Refugees. That right is fast being taken away legislatively and administratively by the governments both of Canada and the United States.

This issue of REFUGE brings the reader up to date on these developments.

The editorial staff takes no pride in this exposition. It is a rearward march along a path that leads back to institutional racism. A curious and ironic twist in the course of two countries whose policies of immigration and refuge have marked them as leaders of the West.

We fervently hope that we have not heard the last word. Yet on both sides of the border reasoned and detailed representations have fallen on deaf ears. Peaceful demonstrations have gone unnoticed in the governmental optic. Alternative courses of action seem to be few.

In this issue we highlight the legislative and administrative procedures for information. We intend to keep our readers abreast of developments throughout this year in briefer updates. The causes of involuntary refugee movement resulting in spontaneous asylum requests have not abated. North American governments cannot wish asylum seekers away. Punitive measures merely compound a problem for our countries' long-standing and ineradicable commitment. Advocates will not shrink in asserting rights of those too powerless to help themselves. Their actions will occupy the attention of REFUGE as long as necessary.

C. Michael Lanphier, Editor

\section{EFFECTS OF U.S. AND CANADIAN POLICIES ON LATIN AMERICAN REFUGEES}

The effects of the Immigration Reform and Control Act of 1986 (also known as the Simpson-Radino Bill) by the U.S. Congress in October of 1986, and the recent cancellation of the Ministerial Permit Program by the Canadian government has created deep concern and apprehension on the part of the Central American refugee community living in the United States. The Simpson-Radino Bill was enacted under the guise of stemming the flood of illegal migration into the United States by refugees seeking better economic opportunities. A similar rationale was given for the adoption of new immigration measures by the Canadian government which retracted the list of special countries (including El Salvador and Guatemala) to which refugees could not be deported. These new legislative changes could have a devastating impact on the Central American refugee community in North America.

The key provisions of the (U.S.) SimpsonRadino Law that impacts most on Central American refugees are those contained in the legalization and employed sanctions. The legalization program applies to persons who have had illegal status in the U.S. prior to January 1, 1982. These persons must also have maintained continuous unlawful residence in the U.S. since that date and a continuous physical presence.

There are several problems with that program when applied to Central Ameri-

\section{Cont'd from page 1}

applicants waiting across the border (with the exception of criminals) until such time as these cases have been decided.

The confluence of these circumstances has created an increasing displaced Central American population on the CanadianU.S. border in upstate New York. At the moment, the State government and churches are providing assistance for the Central Americans. However, a crisis is looming. The measures taken by the Canadian government in February are simply the first in a series of steps to implement a restrictive asylum policy in Canada. Legislation has been introduced (C-55) which, inter-alia would deny the right to apply for asylum to those who are can refugees. The majority of Salvadoran refugees began to flee their country just a few years ago, after the height of the repression and death-squad activity, when the bombings and depopulation of the countryside intensified. Thus, most Salvadoran refugees arrived in the United States after January 1, 1982. They have therefore been disqualified from the amnesty provision in the new Immigration Law. Jos Aguilar, a representative of the Association of Salvadorans and Guatemalans Against Deportations, recently estimated that 80 percent of all Central Americans will not be able to qualify for the amnesty provided in the new law. Those who potentially qualify will face problems of proving their continuous residence, long waiting periods to legalize other immediate family members who do not qualify on their own amnesty, and the fear of being put through deportatron proceedings if denied residency.

Another factor which will make it very difficult for Central Americans to qualify for legalization is the requirement that an applicant prove that he/she will not become a public charge. One must show a steady work history. This provision in the law will have the effect of disqualifying many Central American refugees who have sporadic periods of employment, mainly due to the fact that those who applied for asylum systematically have been denied

Cont'd on next page returnable to a safe third country; e.g., the United States. Salvadorans and Guatemalans in New York, finding themselves already in an alleged "safe third country" (the United States), would face deportation to the home countries from which they originally fled for fear of their lives. They may be among the first victims of increasingly restrictive governmental actions in North America.

Arthur C. Helton is Director, Political Asylum Project, Lawyers Committee for Human Rights. The Lawyers Committee is a non-governmental resource center in the areas of human rights and refugee law. $\mathrm{Mr}$. Helton also chairs an advisory committee of experts to the New York State Inter-Agency Task Force on Immigration Affairs. 